\title{
Comparison of the effects of zinc-silver cream and Nigella sativa oil on wound healing and oxidative stress in the wound model in rats
}

\author{
Ali KUMANDAŞ ${ }^{1, \mathrm{a}, \bowtie}$, Birkan KARSLI $^{1, \mathrm{~b}}$, Aytül KÜRÜ̈$M^{2, \mathrm{c}}$, Miyase ÇINAR $^{3, \mathrm{~d}}$, Ertuğrul ELMA ${ }^{1, \mathrm{e}}$ \\ ${ }^{1}$ Kırıkkale University, Faculty of Veterinary Medicine, Department of Surgery; ${ }^{2}$ Kırıkkale University, Faculty of Veterinary \\ Medicine, Department of Histology; ${ }^{3}$ Kırıkkale University, Faculty of Veterinary Medicine, Department of Biochemistry, Kırıkkale, \\ Turkey. \\ aORCID: 0000-0002-7679-2126; ' ${ }^{\mathrm{O} O R C I D: ~ 0000-0003-4208-3134 ; ~ ' ~}{ }^{\mathrm{ORCID}}$ : 0000-0002-0170-0231; \\ ${ }^{\mathrm{d} O R C I D: 0000-0003-3806-9938 ; ~}{ }^{\mathrm{e} O R C I D: 0000-0001-8795-6512 .}$
}

${ }^{-}$Corresponding author: alikumandas @ gmail.com
Received date: 12.05.2019- Accepted date: 06.08.2019

\begin{abstract}
The present study was undertaken to evaluate of Nigella sativa oil (NSO) and zinc-silver cream in a rat model of wound healing by means of clinical appearance, histopathology, oxidative stress parameters, and biomechanical tests. The rats were divided into three groups, each having twenty animals. Group 1 served as a control having wound. Other two groups received either NS oil or zinc-silver cream in addition to the wound. The study was initiated after the animals rested for 2 weeks for acclimation. Blood samples were collected from 10 randomly selected animals from each group at days $0,3,7$ and 14 for oxidative stress measurements. Differences among groups for blood lipid peroxidation and antioxidant values were determined with respect to biochemical oxidative stress results $(\mathrm{P}<0.01)$. Wound sites of 10 animals from each group were allocated for histopathological examinations, and those of the remaining 10 animals from each group were used in biomechanical testing._Histopathological examination revealed that epithelization occurred in all groups. Inflammatory response with an intensive vascularization was present in the samples of the silver group $(\mathrm{P}<0.01)$. Consequently, zinc-silver group has differed positively in terms of biochemical and biomechanical and histological aspects compared to other groups for wound healing and oxidative stress.
\end{abstract}

Keywords: Nigella sativa oil, oxidative stress, rat, wound healing, zinc-silver.

\section{Çinko-gümüs krem ve çörekotu yağının rat yara modelindeki yara iyileşmesi ve oksidatif stres üzerine etkilerinin karşılaştırılması}

Özet: Bu çalışma, rat yara modelinde çörekotu yağı ve çinko gümüş kreminin klinik görünüm, histopatoloji, oksidatif stres parametreleri ve biyomekanik testlerle değerlendirilerek yara iyileşmesi üzerine etkilerinin karşıllaştırılması amacıyla yapıldı. Çalışmada kullanılan ratlar, her bir grupta 20 hayvan bulunan üç gruba ayrıldı. Grup 1, kontrol grubu olarak belirlendi. Diğer iki gruba sırasıyla yara oluşturulduktan sonra çörekotu yağı ve çinko-gümüş krem uygulandı. Çalışma, hayvanların adaptasyonu için 2 hafta dinlendirilmesinden sonra başlatıldı. Oksidatif stres ölçümleri için 0, 3, 7 ve 14. günlerde her gruptan rastgele seçilen 10 hayvandan kan örnekleri alındı. Kan lipid peroksidasyonu ve antioksidan değerleri için gruplar arası farklılıklar biyokimyasal oksidatif stres sonuçlarına göre belirlendi $(\mathrm{P}<0.01)$. Her gruptan 10 hayvanın sırt kısmındaki yara bölgeleri histopatolojik inceleme için tahsis edildi. Kalan 10'ar hayvanın sırt derileri ise biyomekanik testler için kullanıldı. Histopatolojik inceleme tüm gruplarda epitelizasyonun olduğunu ortaya koydu. Çinko-gümüş grubunun örneklerinde yoğun damarlanma ile inflamatuar yanıt tespit edildi ( $\mathrm{P}<0.01$ ). Sonuç olarak, çinko-gümüş grubu, yara iyileşmesi ve oksidatif stres için diğer gruplara kıyasla, biyokimyasal, biyomekanik ve histolojik yönleri bakımından pozitif olarak farklılık gösterdi.

Anahtar sözcükler: Çinko-gümüş, çörekotu yağı, oksidatif stress, rat, yara iyileşmesi.

\section{Introduction}

Wound healing is a multifactorial process which results in contraction and closure of the wound and restoration of a barrier. Repair of injured tissues occurs in the order in which events occur, including inflammation, proliferation, and migration of various cell types (27). It is a permission that reactive oxygen species (ROS) which are injurious to the wound healing process due to the detrimental effects on cells and tissues (3). Oxidative stress and free radicals have been implicated in impaired wound healing. Topical applications of products with free-radical-purifier properties in animals have shown that the improvement was significantly on wound healing and protecting tissues from oxidative damage (28). Defense 
systems that function in the body are called antioxidants. Their task is to prevent the formation of ROS to prevent the damages of these substances and provide detoxification $(16,24)$.

The uses of natural products, as well as wound dressings with or without antiseptics, are continuously increasing as a consequence of infections related to resistant bacteria in the wound sites (15). There have been numerous studies conducted on wound healing in the recent decade $(5,12,13)$. Materials containing silver ions at different concentrations release them into wound sites at various rates. These silver ions bind to the bacterial cell walls and enzymes. Then, they disrupt the bacterial cell wall structure and consequently prevent bacterial colonization at the wound site. Recently, silver has emerged as an alternative treatment option for combating infection in tissue-injured wounds as well as a treatment for chronic ulcers. Eventually, various silver-based preparations have been introduced to the market in the last few years $(5,13)$.

Experimental studies have shown that unsaturated fatty acids and essential oils, which constitute the most important chemical composition of Nigella sativa oil (NSO), have a wide range of pharmacological effects similar to antipyretic, analgesic, anti-inflammatory, and antimicrobial drugs. It is known that NSO has been used for various medical treatment purposes due to beneficial effects $(14,30)$. There are several studies reporting that NSO has antioxidant properties $(10,31)$. In addition to the antimicrobial and anti-helminthic effects $(1,4)$, it has been shown through clinical and experimental studies that NSO also has anti-inflammatory (19), anti-tumoral (29), antidiabetic (20), and antiulcerogenic effects (2).

This study aims to investigate the effects of Zincsilvercream containing nanosilver and NSO on wound healing in a rat wound model through clinical, biochemical, and histological studies.

\section{Material and Methods}

The study was conducted following the approval of the Kırıkkale University Local Ethics Committee for Animal Experiments (13/06).

Animals: Sixty healthy adult male albino Wistar rats weighing between 250-300 $\mathrm{g}$ were used in the study. The rats were fed a standard rat diet during the study period. Feed and water were given as ad libitum. Rats were divided into 3 groups: 2 treatment groups (NSO group $\mathrm{n}=$ 20 and zinc-silver group $\mathrm{n}=20$ ) and 1 control (control group $n=20$ ). Each group contained 20 animals. Animals were allowed to acclimate for 10 days before treatment.

At the beginning of the study, blood samples were collected from 10 randomly selected animals for control purposes and used in oxidative stress measurements. These animals were rested for 10 days before any surgical applications. The wound was created in all animals by a surgical application. Prior to surgery, animals were treated with $4 \mathrm{mg} / \mathrm{kg}$ xylazine hydrochloride, $45 \mathrm{mg} / \mathrm{kg}$ ketamine hydrochloride for anesthesia. A $4 \times 4 \mathrm{~cm}$ area was shaved on the back of the subjects and a full layer (dermis + epidermis) defect (wound) was created with a $20 \mathrm{~mm}$ diameter sterile punch biopsy instrument after the necessary antisepsis was achieved. For post-operative analgesia, subjects were administered flunixin meglumine subcutaneously at a dose of $2.5 \mathrm{mg} / \mathrm{kg}$. Starting at the day of surgery, a cold cream containing NSO was applied to the NSO group, and a Zinc-silver cream was applied to the nano-silver group once a day for 14 days. The rats in the control group received physiological saline in a similar manner. The wound site was not covered with any kind of dressing. During the study, all animals were caged separately.

On the $14^{\text {th }}$ day of the study, the animals were sacrificed under deep anesthesia, and then 10 animals from each group were used for histological examination, and the remaining 10 animals were used for biomechanical measurements. In addition, wound healing site was evaluated clinically and then photographed.

Biochemical analyses: Blood samples were taken from the heart and collected into both anticoagulated and non-anticoagulated tubes from 10 randomly selected animals from each group on days $0,3,7$, and 14 of the study for biochemical analyses. The lithium heparinanticoagulant blood samples was centrifuged at $3000 \mathrm{rpm}$ for $10 \mathrm{~min}$ at $+4{ }^{\circ} \mathrm{C}$ to obtain plasma. Blood taken to nonanticoagulated tubes were centrifuged for $10 \mathrm{~min}$ at 3000 $\mathrm{rpm}$, and then the serum were separated. Plasma and serum samples were stored at $-80^{\circ} \mathrm{C}$ until analysis. Among oxidative stress markers, Malondialdehyde (MDA) levels in plasma samples were determined by a plate reader as reported by Buege and Aust (8). Furthermore, enzyme activities of catalase (CAT) and superoxide dismutase (SOD) were determined by using commercial ELISA test kits by obtaining a double reading. The amount of nitric oxide in serum samples was determined by the "Vanadium-3-chloride-Gries Reaction" method (21).

Histopathological examinations: The skin samples were collected at the wound sites in $1 \mathrm{~cm}^{2}$ size and kept in $10 \%$ formaldehyde. Fixed tissues were passed through a graded alcohol series and blocked in paraffin through a routine histology procedure. Serial sections at a thickness of $5 \mu \mathrm{m}$ were taken from paraffin blocks at an interval of $300 \mu \mathrm{m}$. Sections were stained with Crossman's modified triple staining technique (11) and examined under a light microscope. Histologic sections were assessed semiquantitatively for changes in the epithelium, inflammatory reaction, and vascularization by using a modified wound scoring from 0 to 4 (Table 1) (17). 
Table 1. The modified scoring system for histological evaluation of wound healing.

\begin{tabular}{clll}
\hline Degree & Epithelization type & Inflammatory reaction & Vascularization \\
\hline $\mathbf{4}$ & Complete epithelization & Very intense inflammatory cell & Extensive vascularization \\
$\mathbf{3}$ & Basal membrane + middle-level epithelium & Medium intense inflammatory cell & Medium intensive vascularization \\
$\mathbf{2}$ & Basal membrane + partial epithelium & Less intense inflammatory cell & Less intensive vascularization \\
$\mathbf{1}$ & Basal membrane + 1-2 epithelium & $1-2$ inflammatory cell & Very little vascularization \\
$\mathbf{0}$ & No epithelization & No inflammation cell & No vascularization \\
\hline
\end{tabular}

*Modified from the scoring system used by Gibson-Corley et al. (17).

Biomechanical tests: For biomechanical tests, skin samples at a size of $2 \times 2 \mathrm{~cm}$, which includes the wound site, were excised out and placed in physiological saline. Measurements were made within 2 hours on fresh tissues. The skin samples, of which the panniculus layer was already removed with prerecorded size, were placed in the machine for tension and tear (Figure 1). Tissue specimens for mechanical testing were measured mechanically with the aid of a tissue stretching and tear-off device.

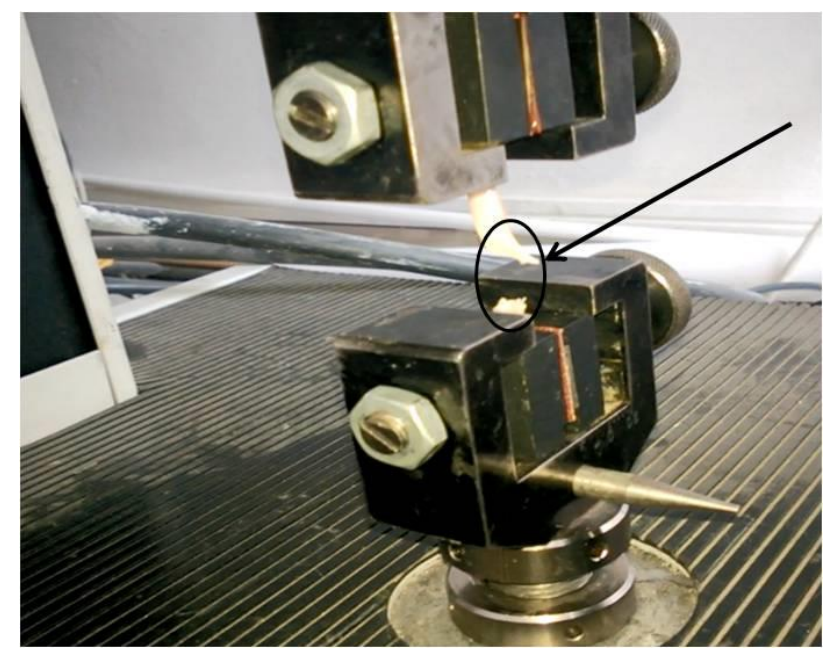

Figure 1. Tissue tension and tear-off test on the $14^{\text {th }}$ day after artificial wounds in rat skin.

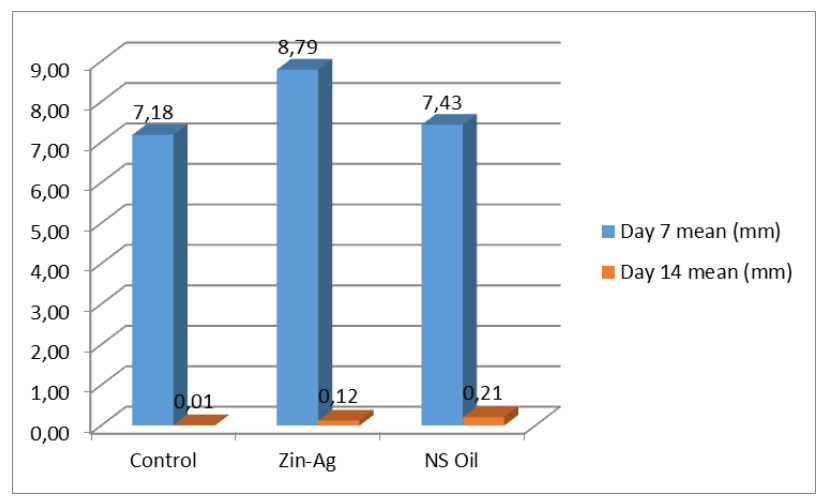

Figure 2. Wound contraction rates of wounded rat skin (mean, $\mathrm{mm}^{2}$ ).
Statistical analysis: The statistical software SPSS 15.0 was used to evaluate the data. The significant difference among groups for biochemical analyses was determined by Kruskal-Wallis test and Mann-Whitney U test after a normality test. Statistical analysis of histopathological findings did not reveal a normal distribution in a normality test. For histopathological analysis, the Kruskal-Wallis test, which is a nonparametric test, was used to determine the differences among groups, and the Mann-Whitney $U$ test was performed to evaluate significance levels. The Spearman's test was used to examine the correlation for epithelialization, inflammation, and vascularization. In order to examine the results of the tissue tensile test, One-way ANOVA and the Tukey-Kramer multiple comparison tests were performed to compare and reveal differences for wound durability. A $\mathrm{P}$ value of $<0.01$ was considered significant for all analyses.

\section{Results}

During the study, there were no unexpected conditions that could affect the course or results of the study. And death was not seen. The wound closure period was the fastest in the control group, and secondly in the silver group, and the lowest in the NSO group. The wound closure rate in $\mathrm{mm}$ with respect to time is graphed in Figure 2. In the control group, the wound line was completely closed in all animals on the $14^{\text {th }}$ day. In the silver group, on the $14^{\text {th }}$ day, the closure rates were close to the control group, but the wound closure was incomplete, and there were wound incrustation in some animals. In the NSO group, the wound contraction rate was the least, and the wound incrustation was observed in more subjects than the latter groups. However, there were no statistically significant differences among groups for the wound closure rate $(\mathrm{P}>0.05)$.

Among the oxidative stress parameters, blood lipid peroxidation and antioxidants including MDA, NO, and CAT were measured with the presence of statistically significant differences among groups $(\mathrm{P}<0.01)$. Compared either to initial blood samples or to the other groups, animals in the control group had the highest serum MDA level while the highest NO level was observed in animals 
of the silver group. Some increases were detected in all groups compared to pre-study SOD value. However, the highest increase was observed in the control group. But, these increases were not statistically significant (Table 2).

Histopathological examinations were evaluated in terms of epithelialization, inflammation, and vascularization at the wound site. The best epithelialization rate was observed in the NSO group, secondly in the control group, and the least in the silver group (Figure 3). The severity of inflammation was the highest in the silver group and the lowest in the NSO group. The degree of vascularization in the silver group was higher compared to the other groups, control, and the NSO groups, both of which had a similar degree of vascularization. There was a negative correlation between epithelialization and severity of inflammation in all groups $(\mathrm{P}<0.01)$. Unlike the other groups, a positive correlation was found between inflammation and vascularization in the NSO group (Table 3).

Table 2. Oxidative stress parameters measured at various periods following forming artificial wounds in rats.

\begin{tabular}{clcccc}
\hline Day & Group & MDA $(\mathbf{n m o l} / \mathbf{L})$ & NO $(\boldsymbol{\mu m o l} / \mathbf{L})$ & CAT $(\mathbf{n m o l} / \mathbf{m i n} / \mathbf{m l})$ & SOD $(\mathbf{U} / \mathbf{m l})$ \\
\hline 10 days prior to study & & $0.86 \pm 0.62$ & $25.57 \pm 3.81$ & $135.19 \pm 59.71$ & $5.57 \pm 0.06$ \\
\hline \multirow{2}{*}{ Day 0 } & Control & $0.92 \pm 0.30$ & $35.80 \pm 5.96^{*}$ & $125.85 \pm 28.33$ & $5.63 \pm 0.04$ \\
& Zinc-silver & $1.03 \pm 0.76$ & $34.66 \pm 7.35$ & $120.40 \pm 81.66$ & $5.57 \pm 0.15$ \\
& NSO & $1.51 \pm 1.57$ & $37.69 \pm 6.55^{*}$ & $118.85 \pm 69.70$ & $5.64 \pm 0.03$ \\
\hline \multirow{2}{*}{ Day 3 } & Control & $1.05 \pm 0.68$ & $28.27 \pm 7.20$ & $127.26 \pm 42.24$ & $5.35 \pm 0.53$ \\
& Zinc-silver & $0.92 \pm 0.73^{*}$ & $31.70 \pm 5.49^{*}$ & $102.2 \pm 83.88^{*}$ & $5.32 \pm 0.40$ \\
& NSO & $1.01 \pm 0.44$ & $30.43 \pm 6.25$ & $109.3 \pm 89.72$ & $5.52 \pm 0.07$ \\
\hline \multirow{2}{*}{ Day 7 } & Control & $2.26 \pm 1.84$ & $37.89 \pm 6.30^{*}$ & $97.94 \pm 57.13$ & $4.66 \pm 1.41$ \\
& Zinc-silver & $0.90 \pm 0.63^{*}$ & $32.17 \pm 7.84$ & $66.80 \pm 23.48^{*}$ & $5.39 \pm 0.24$ \\
& NSO & $1.39 \pm 0.91$ & $40.46 \pm 6.11^{*}$ & $141.57 \pm 60.95$ & $5.51 \pm 0.09$ \\
\hline \multirow{2}{*}{ Day 14 } & Control & $2.85 \pm 2.27$ & $34.10 \pm 11.09$ & $178.85 \pm 8 ., 32$ & $5.38 \pm 0.19$ \\
& Zinc-silver & $1.03 \pm 0.58^{*}$ & $36.01 \pm 6.06^{*}$ & $114.56 \pm 19.63^{*}$ & $5.47 \pm 0.08$ \\
& NSO & $1.16 \pm 0.75$ & $34.70 \pm 7.12$ & $138.35 \pm 25.34$ & $5.46 \pm 0.13$ \\
\hline
\end{tabular}

Data are expressed as mean \pm SD $(n=10)$.

*Indicates significant differences. When compared to the values measured 10 days prior to the study.

$\mathrm{P}<0.01$.

MDA: Malondialdehyde, NO: Nitric oxide, CAT: Catalase, SOD: Superoxide dismutase.

Day 0: The day right after surgery.

Table 3. The modified scoring system data for histological evaluation of artificial wounds in rats.

\begin{tabular}{lccc}
\hline & Control group & Zinc-silver group & NSO \\
\hline Epithelization & $3.5(0-4)$ & $3.4(1-4)$ & $3.9(2-4)$ \\
Inflammation & $1.4(0-4)$ & $1.5(0-4)$ & $0.6(0-4)$ \\
Vascularization & $3.3(2-4)$ & $3.9(2-4)$ & $3.3(2-4)$ \\
\hline
\end{tabular}

Data are given median (min-max). $\mathrm{n}=10$

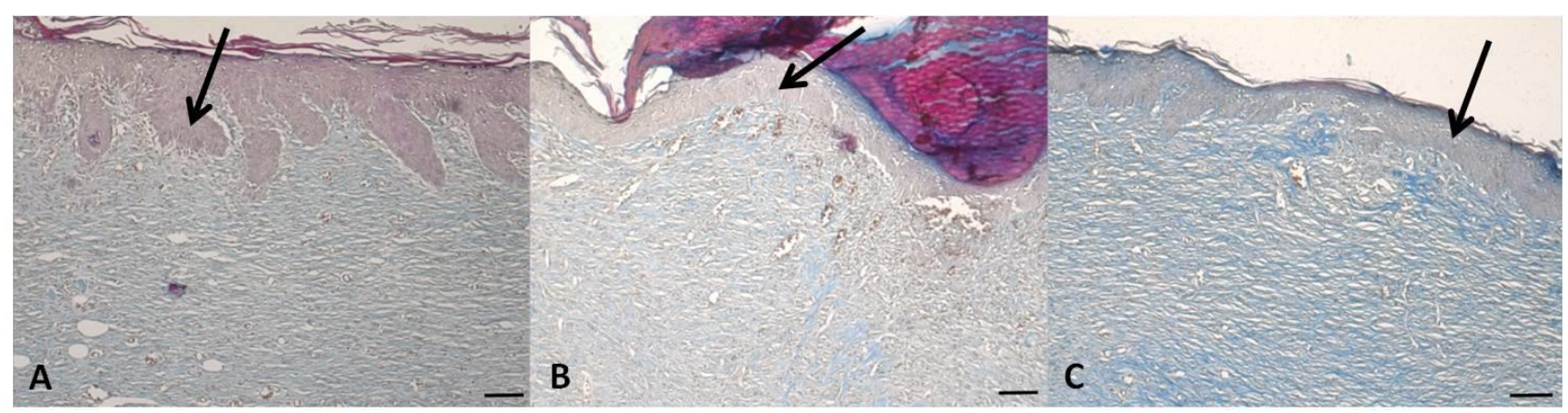

Figure 3. Histopathological images of the $14^{\text {th }}$ day in the rat wound model. A: control group, B: NSO group, C: Zinc-silver group (H\&E, 10x, bar: $100 \mu \mathrm{m})$, Arrows: Epidermis. 
In the control group, it was determined that no load could be carried during the biomechanical tests despite the good completion of the epithelialization in the histopathological examination. As seen in Figure 4 representing the control samples, the tissue was Instantaneously ruptured from the wound site during the tension and tear test, and there was a brief decrease in the tissue load carrying capacity. The first breakpoint on the test chart of the control group shows that the holding force of the wound is very low.
There were statistically significant differences among groups for a time, load, tissue tension, and stress based on the tissue tension and tear test $(\mathrm{P}<0.01)$. In the tissue tension and tear test, the control group had no durable skin resistance despite the best wound healing appearance (Table 4). The strongest tissue to bear the highest load was those in the silver group (Figure 5). Then, all of the data were evaluated in Table 4 , and mean values were found to be relatively high.

Table 4. Evaluation of tissue tension and tear test results.

\begin{tabular}{|c|c|c|c|c|c|c|c|}
\hline Test Parameters & Group & Mean \pm SE & Median & IQR & Mean rank & $\mathbf{P}$ & $\mathbf{Z}$ \\
\hline \multirow{3}{*}{ Times } & Control & $112.20 \pm 3.21^{*}$ & 93.67 & 97.81 & 1557.05 & \multirow{3}{*}{0.001} & \multirow{3}{*}{-0.730} \\
\hline & Zinc-silver & $90.25 \pm 1.75^{*}$ & 86.87 & 85.27 & 1449.84 & & \\
\hline & NSO & $87.86 \pm 1.68^{*}$ & 85.01 & 85.67 & 1442.14 & & \\
\hline \multirow{3}{*}{ Load } & Control & $5.60 \pm 0.35^{*}$ & 6.87 & 14.58 & 1607.69 & \multirow{3}{*}{0.001} & \multirow{3}{*}{-4.232} \\
\hline & Zinc-silver & $10.41 \pm 0.28^{*}$ & 8.79 & 14.14 & 1491.51 & & \\
\hline & NSO & $8.75 \pm 0.25^{*}$ & 6.25 & 12.13 & 1329.66 & & \\
\hline \multirow{3}{*}{ Extension } & Control & $18.25 \pm 0.53^{*}$ & 15.29 & 16.50 & 1577.92 & \multirow{3}{*}{0.001} & \multirow{3}{*}{-0.736} \\
\hline & Zinc-silver & $14.29 \pm 0.29^{*}$ & 13.68 & 14.01 & 1439.61 & & \\
\hline & NSO & $13.87 \pm 0.28^{*}$ & 13.41 & 14.15 & 1411.38 & & \\
\hline \multirow{3}{*}{ Strain } & Control & $0.61 \pm 0.02^{*}$ & 0.51 & 0.55 & 1510.52 & \multirow{3}{*}{0.001} & \multirow{3}{*}{-4.755} \\
\hline & Zinc-silver & $0.48 \pm 0.01^{*}$ & 0.46 & 0.47 & 1369.19 & & \\
\hline & NSO & $0.55 \pm 0.01^{*}$ & 0.54 & 0.57 & 1549.40 & & \\
\hline \multirow{3}{*}{ Stress } & Control & $0.45 \pm 0.01^{*}$ & 0.36 & 0.53 & 1508.32 & \multirow{3}{*}{0.001} & \multirow{3}{*}{-3.522} \\
\hline & Zinc-silver & $0.38 \pm 0.01^{*}$ & 0.32 & 0.52 & 1392.25 & & \\
\hline & NSO & $0.47 \pm 0.01$ & 0.34 & 0.67 & 1528.59 & & \\
\hline
\end{tabular}

Data are expressed as mean $\pm \mathrm{SE}(\mathrm{n}=10)$.

$\left.{ }^{*}\right)$ Indicates significant differences among groups $\mathrm{P}<0.01$.

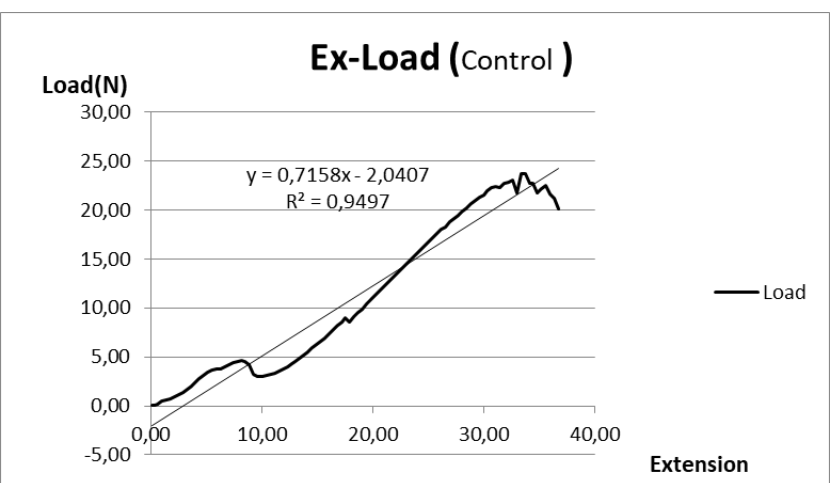

Figure 4. The control group's extension-load graph, obtained through measurement of the wounded rat skin.

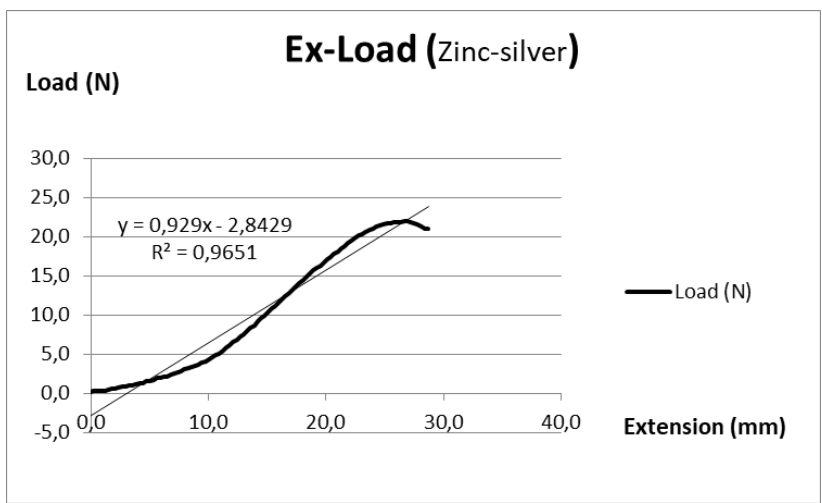

Figure 5. The zinc-silver group's extension-load graph, obtained through measurement of the wounded rat skin. 


\section{Discussion and Conclusion}

Wound closure involves a series of events and concomitant interaction of numerous molecules including antioxidants $(22,23,26)$. Antioxidants are substances that prevent the progression of peroxidation and reacts quite rapidly with radicals. Since free radicals play a definite role in the pathogenesis of wound, antioxidant activity has been investigated in many studies (6). The results of our study showed that topical silver application increases antioxidant activity by inhibiting lipid peroxidation, and also NO level increases in the silver group when compared to baseline values (Table 2). These results confirm the potent wound healing activity of silver. Thus, the wound healing activity may occur because of the potent-radicalscavenging activity. Lipid peroxidation begins as a consequence of free radicals oxidating polyunsaturated fatty acids. MDA is the last product of lipid peroxidation $(9,22,23,26)$. Increase in the serum MDA levels occurs either as a consequence of an increase in free radicals in the body or reduced antioxidant defense mechanisms. In the present study, the highest increase in serum MDA level was observed in the control group while the silver group had the lowest increase. This confirms that nanosilver may have a reducing effect on the lipid peroxidation products, or it may itself have a strong antioxidant effect $(9,22)$.

The increase of free radicals and lipid peroxidation in injured tissue may thereby predispose to accelerated catalase and catalytic activity for poor wound healing and organ failure because of the disrupted cell membrane structure and permeability (16). In the present study, the lowest plasma serum CAT level was observed in zincsilver group. This result may be due to possible antiinflammatory effects $(9,22)$.

SOD is known as a protective enzyme against oxidative stress, which converts superoxide radical to hydrogen peroxide and to molecular oxygen. During the study, a further increase in the SOD activity was found in the control group as compared to the other groups. Also, in this study, there were some changes seen in SOD levels in all the groups; however, no statistically significant change was observed. Thus, SOD may not be involved in the healing process of the rat wound model we applied.

NO production is an expected outcome during a normal wound healing process. Some studies have reported that nitric oxide synthase inhibitors delay wound healing, while the administration of nitric oxide accelerates wound healing $(22,26,32)$. Some authors have reported that inducible nitric oxide synthase (iNOS) reaches peak levels 4 - 6 days after wound formation and accelerates wound healing (9). Studies have shown that nitric oxide is effective in wound healing, and also that it plays an important role in collagen accumulation $(7,18$, $25)$. Increase in NO level may accelerate wound healing by increasing angiogenesis, endothelial and epithelial cell proliferation, and migration (26). In our study, serum NO levels in all study groups were found to increase during the study period according to the control measurements, and they reached their highest level on the $7^{\text {th }}$ day. The increase of NO level to the maximum level in the nanosilver group on the $14^{\text {th }}$ day (after collecting the laboratory samples) suggests that the best contributory effect in the wound healing processes is in this group. This was also confirmed by histopathological examination and mechanical tests.

Silver is widely used in wound healing due to its antiinflammatory and antiseptic effects, although there are also some data causing controversies as well. In fact, even though nano-silver-containing products for clinical applications are currently in use, it is also possible to encounter many opposing views within these multiple data sets. It is clear that commercial nano-silver-containing products that have been tested for a cytotoxic activity will contribute to further knowledge about the subject, supported by further, planned in vivo studies in terms of antibacterial effects and inflammation. It is thought that some data obtained in the present study are similar to other groups, and there are statistical differences between them, but still, it is thought that the silver group is superior to other groups in terms of wound healing. Histologically, the reason for the increase in inflammation compared to the other groups is thought to be that the nanosilver stimulates the inflammatory response and contributes to the formation of connective tissue. The silver group, which has been found to be the best group for tissue bond development, has also been the group with the highest load carrying capacity $(21.95 \mathrm{~N})$ in the tissue stretching and breakout test; thus, making it the best group for skin healing. It has been concluded with the post healing data, zinc-silver group differs positively in terms of clinical and biochemical and histological aspects compared to other treatment groups, and thus it may be a clinically useful product for wound healing.

Studies on experimental burn wounds in rats have reported that epithelialization and granulation are better in subjects treated with NSO than in other groups (30). In the present study, the NSO group's epithelization in the histological section was found to be the best group that contradicts with the previously published articles. The inflammatory response was found to be at the least level in NSO group as well. In the histological evaluation, Epithelization and connective tissue proliferation were better in NSO group compared to those in the control group (Figure 4). But, vascularization and connective tissue formation were found to be lower compared to those in the silver group. This finding is also supported by the tissue tensile tear test results of the study (Figure 6). 


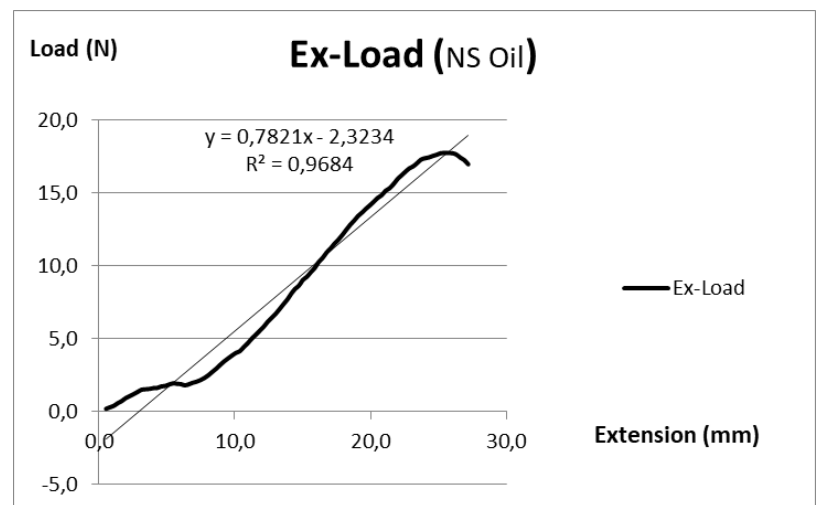

Figure 6. The NSO group's extension-load graph, obtained through measurement of the wounded rat skin.

Mechanical resistance is a characteristic that determines the quality of healing in skin wounds. The mechanical properties of the skin are used to examine changes in the skin due to aging or in vivo or ex vivo evaluation of wound healing studies in experimental animals. In the biomechanical tests, the control group showed the lowest load carrying capacity (Mean Load: $4.60 \mathrm{~N}$ ). The lowest load carrying capacity is also reflected in the histomorphological study in which epithelialization and connective tissue formation were incomplete in this group.

In conclusion, although lower clinical healing appearance, zinc-silver seems to have a better healing capacity in a rat wound healing model due to best histological healing with an increase anti-oxidant induction and a higher load carrying capacity. Healing capacity resulting from NSO lower compared to that of zinc-silver. Further studies are needed to reveal the molecular background of zinc-silver and NSO effects on wound healing, such a complex multifactorial process.

\section{Acknowledgments}

This study was supported by the Kırıkkale University Scientific Research Project Coordination Unit (KÜBAP No: 2013 / 80).

\section{Conflict of Interest}

The authors declared that there is no conflict of interest.

\section{References}

1. Agarwal R, Kharya MD, Shrivastava R (1979): Antimicrobial and anthelmintic activities of the essential oil of Nigella sativa Linn. IJEB, 17, 1264-1265.

2. Akhtar AH, Ahmed KD, Gilani SN, et al (1996): Antiulcer effects of aqueous extract of Nigella sativa and Pongamia pinnata in rats. Fitoterapia, 3, 195-199.

3. Aliyeva E, Umur S, Zafer E, et al (2004): The effect of polylactide membranes on the levels of reactive oxygen species in periodontal flaps during wound healing. Biomaterials, 25, 4633 - 4637.

4. Arici M, Sagdic O, Gecgel U (2005): Antibacterial effect of Turkish black cumin (Nigella sativa L.) oils. Grasas Aceites, 56, 259-262.

5. Atiyeh BS, Costagliola M, Hayek SN, et al (2007): Effect of silver on burn wound infection control and healing: Review of the literature. BURNS, 33, 139-148.

6. Baboir BM (1978): Oxygen-dependent microbial killing by phagocytes (first of two parts). N Engl J Med, 298, 629668.

7. Benrath J, Zimmermann M, Gillardon F (1995): Substance $P$ and nitric oxide mediate wound healing of ultraviolet photodamaged rat skin: evidence for an effect of nitric oxide on keratinocyte proliferation. Neurosci Lett, 200, 17-20.

8. Buege JA, Aust SD (1978): Microsomal lipid peroxidation. Methods Enzymol, 52, 302 - 310.

9. Bulgrin JP, Shabani M, Chakravarthy D, et al (1995): Nitric oxide synthesis is suppressed in steroid-impaired and diabetic wounds. Wounds, 7, 48-57.

10. Burits M, Bucar F (2000): Antioxidant activity of Nigella sativa essential oil. Phytother Res, 14, 323-328.

11. Denk H, Künzele H, Plenk H, et al (1989): Romeis Mikroskopische Technik. Wien, München, Baltimore.

12. Diegelmann RF, Evans MC (2004): Wound healing: an overview of acute, fibrotic and delayed healing. Front Biosci, 9, 283-289.

13. Dorsett-Martin WA (2004): Rat models of skin wound healing: A Review. Wound Rep Reg, 12, 591-599.

14. Durmus AS, Han MC, Yaman I (2009): Comparative evaluation of collagenase and silver sulfadiazine on burned wound healing in rats. FÜ Sağ Bil Vet Derg, 23, 135-139.

15. Engin A (2004): Yara iyileşmesi. 266-277. In: İ Sayek (Ed), Temel Cerrahi. Güneş Kitabevi, Ankara.

16. Freeman BA, Crapo JD (1982): Biology of disease: free radicals and tissue injury. Lab Invest, 47, 412 - 424.

17. Gibson-Corley KN, Olivier AK, Meyerholz DK (2013): Principles for valid histopathologic scoring in research. Vet Pathol, 50, 1007-1015.

18. Gubta A, Singh RL, Roghubir R (2002): Antioxidant status during cutaneous wound healing in immunocompromised rats. Mol Cell Biochem, 241, 1-7.

19. Houghton PJ, Zarka R, Heras B, et al (1995): Fixed oil of Nigella sativa and derived thymoquinone inhibit eicosanoid generation in leukocytes and membrane lipid peroxidation. Planta Med, 61, 33-36.

20. Meral I, Yener Z, Kahraman T, et al (2001): Effect of Nigella sativa on glucose concentration, lipid peroxidation, anti-oxidant defence system and liver damage in experimentally-induced diabetic rabbits. J Vet Med A Physiol Pathol Clin Med, 48, 593-599.

21. Miranda KM, Espey MG, Wink AD (2001): A rapid, simple spectrophotometric method for simultaneous detection of nitrate and nitrite. Nitric Oxide, 5, 62 - 71.

22. Musalmah M, Fairuz AH, Gapor MT, et al (2002): Effect of Vitamin $E$ on plasma malondialdehyde, antioxidant enzyme levels and the rates of wound closures during wound healing in normal and diabetic rats. Asia Pac J Clin Nutr, 11, S448-51. 
23. Özyurt H, Irmak MK, Akyol Ö, et al (2001): Caffeic acid phenethyl ester changes the indices of oxidative stress in the serum of rats with renal ischemia-reperfusion injury. Cell Biochem Funct, 19, 259-63.

24. Pham-Huy LA, He H, Pham-Huy C (2008): Free radicals, antioxidants in disease and health. Int $\mathrm{J}$ Biomed Sci, 4, 89-96.

25. Schaffer MR, Tantry M, Efron PA, et al (1997): Diabetes impaired healing and reduced wound nitric oxide synthesis: a possible pathophysiologic correlation. Surgery, 121, 5139.

26. Serarslan G, Altuğ ME, Kontaş T (2007): Kafeik asid fenetil ester'in insizyonel yara modelinde plazma lipid peroksidasyonu, antioksidan durum ve nitrik oksit seviyesi üzerine etkisi. Türkderm, 41, 11-14.

27. Sidhu GS, Mani H, Gaddipatti JP et al (1999): Curcumin enhances wound healing in streptozotocin-induced diabetic rats and genetically diabetic mice. Wound Rep Reg, 7, 362 -374 .

28. Thiem B, Grosslinka O (2003): Antimicrobial activity of Rubus chamaemorus leaves. Fitoterapia, 75, 93 - 95.

29. Worthen DR, Ghosheh OA, Crooks PA (1998): The invitro anti-tumor activity of some crude and purified components of the black seed, Nigella sativa L. Anticancer Res, 18, 1527-1532.

30. Yaman I, Durmus AS, Ceribaşı S, et al (2010): Effects of Nigella sativa and silver sulfadiazine on burn wound healing in rats. VET MED-CZECH, 12, 619-624.

31. Yaman I, Balıkçı E (2010): Protective effects of Nigella sativa against gentamicin-induced nephrotoxicity in rats. Exp Toxicol Pathol, 62, 183-190.

32. Yamasaki K, Edington HDJ, McClosky C, et al (1998): Reversal of impaired wound repair in iNOS-deficient mice by topical adenoviral-mediated iNOS gene transfer. J Clin Invest, 101, 967-71. 